NEW LOCALITIES FOR THE MINERALS BROOKITE, NATROLITE, AND BARYTES.

SrR, - I have recently discovered a new locality for Brookite and Natrolite in Caernarvonshire (the old locality is near Tremadoc). The Gimblet rock, Pwllheli, consists of a compact ophitic dolerite containing labradorite, large brilliant crystals of augite, and magnetite. Fissures traverse the rock in all directions, and are filled with quartz and calcite. Small bright crystals of Brookite are imbedded in the dolerite and project into the fissures; they are in many cases surrounded and covered by calcite, but are revealed on removal of the latter by hydrochloric acid. The largest "crystals have a diameter of one quarter of an inch, and are tabular in habit: the large faces are striated in the direction of the vertical axis.

The mineral Natrolite occurs in geode-like cavities in the dolerite, and is intimately associated with calcite and quartz. The radiating spherical groups of Natrolite are white in colour, and from one quarter to half an inch in diameter.

Last August I had occasion to visit Dosthill, near Tamworth, and am able to add a new mineral to the list of those hitherto known as occurring in Warwickshire. The mineral is Barytes, and occuts in veins an inch in diameter in the Cambrian shales. The crystals have a beautiful reddish colour due to enclosed ferric oxide. 122, Linwood Road, Handsworth, Birmingham. W. J. Harrison, Jun.
Nov. 3rd, 1894 .

\title{
GLACIAL GEOLOGY.
}

SIR,-Although I scarcely think that Sir H. H. Howorth's letter, published in your November Number, calls for any remark from me, I cannot refrain from noticing a few of his arguments, as they reflect strongly upon his controversial methods.

It is an impertinence, it would seem, for me to say anything about Switzerland and its glaciers, or to look at them, seeing that others Lave already been there, and that a whole library was written upon the subject before I was born! Indeed, it was an unjustifiable public advertisement to say that I had ever been there or had even seen a glacier! At the same time be regards it as preposterous that "those who have never studied the mechanics of ice in a laboratory, and, what is more strange, have never seen a glacier at all," should write upon the subject. There is clearly no way out of the difficulty; I must do something preposterous or be impertinent, if I am legitimately to interest myself in glacial matters!

His answer to the demand I made for a statement of the angle of slope at which a glacier ceases to flow is equally characteristic. We learn that Forbes "collected considerable evidence to show what the least angle is upon which ice will begin to move. This is the slope, the least slope, available." In other words it is "as much again as half."

We also learn that although the Antarctic continental ice may move into deep water, and present a vertical wall of ice to the ocean $4 \tilde{0} 0$ miles long and more than 150 feet high, to imagine that con- 
tinental Arctic ice can do the same thing required "the invention of Croll, who, sitting in his arm-chair, and endowed with a brilliant imagination, imposed upon sober science the extraordinary postulate"; and the sober, simple, scientific explanation of every difficulty, imagrined or real, is that the upheaval of "the highest masses of land on the earth, including the massive mountains of Asia and the American Cordillera," was "very rapid, if not sudden," and that "the breaking up of the earth's crust at the time, of which the evidence seems to be overwhelming, necessarily caused great waves of translation to traverse wide continental areas." His own words, " no science but long-suffering geology would tolerate the absurdity," seem more to the point here.

There need be no loss of temper or heated argument on the subject. Neither dogmatic assertion nor the weight of authority will ultimately prevail. In the eyes of many it may be impertinent of me to have opinions on this or any other subject; but all, it seems to me, have a right to add their mite in the hope that it will assist in the elucidation of the truth. Of one thing I am sure, and that is, that although we have been preceded by Forbes, Agassiz, Bishop Rendu, Ramsay, and Tyndall, and a host of others who have ceased to work in this world, there still remains very much to be done.

10, Charnwood Street, Derby.

R. M. Deeley.

THE "SOUTHERN DRIFT."

Sir,-I am sorry that in my paper there should have been any statement which Prof. Prestwich or anyone else could consider misleading. In mentioning the name of Prof. Phillips, as well as that of Prof. Prestwich, in connection with the Southern Drift, wy only object was to afford information to those unacquainted with the literature of the subject. I suppose I put Phillips first because the date of the work referred to (1871) was earlier than the quoted paper of Prof. Prestwich. ${ }^{1}$ But no one who is at all acquainted with Geology, or even with contemporary history, can suppose that the slight reference in Phillips's work bears any sort of comparison to the full and exhaustive work of Prof. Prestwich, who has done more than any other geologist to create an interest in the once despised "superficial deposits." Nor is it any disparagement of Prof. Phillips's reputation as a geologist that his treatment of these deposits in the Thames district should be necessarily imperfect, and to some extent based on information supplied by others. It is evident that he knew of a hill-gravel formed by "currents from the south transporting flints and sarsen-stones"; but the passage quoted by Prof. Prestwich contains all that he has said on the subject in the work referred to. He has also figured neolithic forms as "Implements from the drift."

1 Prof. Prestwich writes:- “'This is a mistake. Prof. Prestwich's first paper on this subject was published in 1847. Besides, flint, gravel, and sarsen-stones alone do not prove a drift from the south. It might as well have been from the west or north-west." -.J. P. 